\title{
The Mystery of Development: A Comparison of South Korea and Zambia Development Trajectory
}

\author{
Ruth Endam Mbah ${ }^{1,2,3^{*}} \quad$ Divine Forcha Wasum ${ }^{4}$ \\ 1.International Center for IT and Development (ICITD), Southern University and A\&M, LA, USA. \\ 2.Department of Public Policy, Southern University and A\&M, LA, USA. \\ 3. Nelson Mandela Institute for Research (NMIR) \\ 4.CIFE, Centre International de Formation Européenne
}

\begin{abstract}
Development, since its birth from The Rise of the Age of Enlightenment remains a mystery. Development though infinite, has no standardized formula which countries worldwide can use to move from one end of the continuum to the other. What makes it more complex is the fact that science is not static but evolves every second due to the inquisitive nature of man. This is the reason why development will forever remain on the lips of every policy maker no matter the country's stage of development. Einstein once articulated that politics is harder than science. The Eastern Asian countries like China and South Korea astonishing economic explosion have broken the status quo. At independence, South Korea and Zambia were almost at the same stage of development in the early 1960s. Today, it is no longer the case. South Korea has become the Miracle of Development and a modern industrial nation while Zambia has become a Development Disaster and a postal child of deindustrialization. The question is, what happened?
\end{abstract}

Keywords: Development, deindustrialization, Korea, Zambia, national integration, development-miracle

DOI: $10.7176 / \mathrm{JAAS} / 59-05$

Publication date: December $31^{\text {st }} 2019$

\section{Introduction}

Development, though infinite can be a very painful process. Every developing nation is faced with issues of national integration, political survival and development remains at the center of every third world country. The transition from agrarian to industrial and later postindustrial remains a night mare to many nations of the world and seems like impossibility to others. It is a rarity to see a nation move from agrarian to preindustrial and to industrial. It is therefore, a miracle to see that all the nations that have been able to make this transition are in Asia. South Korea is one of the famous miracles of development in the world as it unexpectedly transition from one of the poorest countries in the world to a developed high income nation in just one generation. This South Korea miracle is commonly known as Miracle on the Han River (refers to the era of rapid economic growth in South Korea succeeding the Korean War (1950-1953), during which South Korea transformed from a developing country to a developed country. ${ }^{1}$ This has conveyed South Korea to the ranks of elite countries in the OECD and the G-20. Einstein once said that politics is harder than science. Indeed development can equally be very frustrating for some. According to Inglehart, the stages of development are not linear. Growth is not linear but non-linear. Countries which used to be rich in Africa like Zambia have become a postal child of how a country can deindustrialize and run into ruins. Unlike South Korea, development has been a night mare for Zambia since independence when both countries were almost at the same level of development. This difference pushed Jeff Frieden to do a comparison between South Korea and Zambia in his book. How come both used the authoritarian model of development at independence but South Korea succeeded while Zambia failed?

\section{Critical Variables Present in the Development Upswing of South Korea}

Most developing countries began development in the 1950s and 1960s under authoritarian regimes. Unlike Zambia, South Korea effectively used Mitchel Orenstein authoritarian model of development to its advantage. According to Michael Shafel, South Korea had a strong state and proper policy explanation. Park used his authoritarian power to redefine the state goal and hence, made economic growth the measure of political performance and Korea progress. Early in his presidency, the dictator Park Chung Hee launched the variant 3.5, export-led growth policy. Francis Fukuyama describe this model as one in which the state intervenes to guide economic development much more strongly than in the free market one, while respecting private property rights. South Korea, under strongman Park Chung-Hee, focused on building up large economic champions, or chaebols (business conglomerates), even against American advice to focus on small- and medium-sized companies. That policy laid the foundation for successful South Korean brands in the world market, such as Samsung and LG, although it came at a price in terms of political corruption in the close ties between business and political elites. KoFID and ReDI argue that the focus on conglomerates led to the chaebols exploiting their monopoly status,

\footnotetext{
${ }^{1}$ Kleiner, JüRgen (2001). Korea, A Century of Change. ISBN 978-981-02-4657-0.
} 
fostering increasing economic inequality. Park took a realistic approach to corruption. Instead of cracking down on corrupt businessmen as urged by the US, he expropriated their bank shares and assigned them to invest in import-substitution industries, such as fertilizers, a point made in Catalyzing Development, a book on aid edited by Homi Kharas, Koji Makino and Woojin Jung.

Another critical variable to South Korea's success was the effective use of foreign aid. South Korea benefited from big injections of foreign aid, first from the US, then Japan. According to a briefing paper from KoFID, a South Korean network of civil society organizations, and ReDI, a South Korean think-tank, points out that the US offered about \$60bn in grants and loans to South Korea between 1946 and 1978. During the same era, the total amount of aid provided by the US to the entire African continent was $\$ 68.9 \mathrm{bn}$. Korea which was considered by the US as an important ally during the cold war undisputedly used the aid well. The South Korean regime did not squander the aid it received like most African countries through embezzlement. Even when there was corruption, Park used a pragmatic approach to handle it so that it benefited the economy. ${ }^{1}$

Furthermore, South Korea had a comparative advantage in technology and design. South Korean firms have a solid record for investing in productive capacity. South Korea's capital investments in research and development are among the highest in the world relative to national income. South Korea invests gigantic sums in R\&D and design and its companies make world-beating products. Companies such as LG and Samsung have been sweeping international design awards. In January 2009, South Korea formed the 47-member Presidential Council Nation Branding, a government initiative meant to coordinate all nation-branding efforts. It includes 8 ministers, numerous business leaders, and professors who embarked on a ten-point "Brand Korea" action plan. ${ }^{2}$

Additionally, South Korea had a very strong manufacturing industry. According to Richard D. \& Roland V. (2010), South Korea's economic miracle was fashioned by manufacturers, that is, giant enterprises that consumed labor, fuel, and materials and cranked out tangible objects: steel, ships, buildings, cars, bridges, appliances, memory chips, TVs, and mobile phones. South Korea's economy is more reliant on manufacturing than any other country in the Organization for Economic Co-operation and Development (OECD), partially because the government sustains focus on manufacturing tapped capital, talent, and other resources away from the domestic-service industries. During the 1970s and 1980s, South Korea became a leading producer of ships, including oil supertankers, and oil-drilling platforms. Notable Korean shipbuilders are Hyundai Heavy Industries, Samsung Heavy Industries, Daewoo Shipbuilding \& Marine Engineering, and the now bankrupt STX Offshore \& Shipbuilding. ${ }^{3}$ The automobile industry was also one of South Korea's major growth and export industries in the 1980s. South Korea today has developed into one of the world's largest automobile producers. Hyundai KIA Automotive Group is Korea's largest automaker. ${ }^{4}$ Construction too, has been an important South Korean export industry since the early 1960s and remains a critical source of foreign currency and invisible export earnings. Korea's largest construction companies include Samsung C\&T Corporation, which built some of the highest building's and most noteworthy skyscrapers such as three consecutively world's tallest buildings: Petronas Towers, Taipei 101, and Burj Khalifa. ${ }^{5,6}$ South Korea who ones greatly depended on the USA for armed forces supplies now largely produces and exports them. Example of its key military export projects include the T-155 Firtina self-propelled artillery for Turkey; the K11 air-burst rifle for United Arab Emirates; the Bangabandhu class guided-missile frigate for Bangladesh; fleet tankers such as Sirius class for the navies of Australia, New Zealand, and Venezuela; Makassar class amphibious assault ships for Indonesia; and the KT-1 trainer aircraft for Turkey, Indonesia and Peru. ${ }^{7}$

\section{Omitted Critical Variables that led to the Downward Spiral in Zambia's Development}

At independence, while Mitchel Orenstein authoritarian model of development worked well for South Korea it did not for Zambia. Michael Shafer in his 1990 Comparative Politics established that Zambia's weak state and inappropriate policy pursuit made it to waste its revenue opportunities. Zambia citizens expected the new government to alter the colonial political economy at independence as it offered opportunities for innovation. In 1964, Zambia's high tax revenues were supplemented by the ending royalty payment to the BSA Company and revenue transfer to Southern Rhodesia. Zambia's lack of national identity and the experience with central rule was due to its colonial past. It therefore became difficult to build national political organization and manage sectional difference. Despite the money available and the need to diversify, Zambia lacked the administrative capacity to plan and implement radical changes and thus, their choice of development policies aggravated these problems.

\footnotetext{
${ }^{1}$ https://www.theguardian.com/global-development/poverty-matters/2011/nov/28/south-korea-development-model

${ }^{2}$ Christopher Graves, 2010. Designing a distinctive national brand

${ }^{3}$ South Korea: Shipbuilding". Library of Congress.

${ }^{4}$ South Korea: Automobiles and Automotive Parts". Library of Congress.

${ }^{5}$ Hansen, Karen; Zenobia, Kent (2011-03-31). Civil Engineer's Handbook of Professional Practice. ISBN 9780470901649.

6 "Building -- Samsung C\&T". Retrieved 11 June 2016.

7 "South Korea: Armaments". Library of Congress.
} 
More so, the commodity curse was a significant factor to the downward spiral of Zambia's development. Zambia reached independence entirely dependent on copper mining. Zambia is a copper economy and its discovery tied it to the international economy giving it a modern industrial infrastructure. Copper endowed the newly independent state with cash reserves and revenue that were the envy of Africa. Copper was one of Zambia's principal sources of government revenue at independence as it accounted for $60 \%$ of GDP, $40 \%$ of value added, $53 \%$ of government revenue, and $92 \%$ of foreign exchange earnings and employed $20 \%$ of those in paid employment. Unfortunately, in 1975, a prolonged depression on copper prices around the world practically wiped out government revenue from copper and increased foreign debt to extraordinary levels. Even though, economic policy makers in Zambia after the depression in copper tried to shift government revenue total dependence on copper to agriculture and manufacturing industries, it failed. This economic sectorial shift failed and today Zambia faces more serious problems than ever without the buffer once provided by copper. Its debts exceeded its capacity to pay, making it hard to find capital to diversify and it depended more on imports than exports and though its population grew, employment remained stagnant. ${ }^{1}$

Additionally, Zambia's crisis and its response in the 1970s was a critical variable to its downward spiral. The collapse of the price of copper devastated the Zambian economy. In just a single year, its terms of trade fell by half, export receipts decreased by $40 \%$ and government revenue from mining collapsed by $80 \%$. This affected its balance of payment as its budget went from a surplus to a deficit. Though the government tried to contain the deficit between 1976 and 1979, external debt and commercial payment arrears ascended. Policy makers thought the crisis was just a temporal night mare that will soon end. Due to this misconception, they did not consider devaluation, reordering industrial policy or restructuring the parastatals as it would have discredited past policies and pose political problems. Hence, Zambia's future forward movement was haunted by the past due to the double burden it bears of the past: the consequence of copper dependence and of state actions taken to counter them. ${ }^{24}$

Furthermore, Michael Shafel following from the comparison of Jeffry Frieden between South Korea and Zambia postulated that Zambia is strategically insignificant in a turbulent region, which had suffered for its support for freedom in Mozambique and Zimbabwe. Zambia too has not had a powerful benefactor nor received large amount of aids like South Korea who was one of the USA key Third World allies and the recipient of lavish amount of aid. Also, Zambia state's limited institutional development surely constraint its ability to restructure the economy unlike South Korea whose state institutions possess far greater managerial and technical capacity. ${ }^{27}$

\section{Comparison of Present Day South Korea versus Zambia}

While South Korea has experienced what has come to be known as the 'Miracle of Development,' Zambia has become the postal child of deindustrialization. Zambia is a proof of how frustrating and devastating development can be. Both nations at independence were almost at the same stage of development but today they are at extreme ends of the development Continuum. According to the Heritage Foundation analysis, South Korea's economic freedom score is 73.8 , making its economy the 27 th freest in the 2018 Index while Zambia's economic freedom score is 54.3, making its economy the 132nd freest in the 2018 Index. Regionally, while South Korea is ranked 7th among 43 countries in the Asia-Pacific region, and its overall score is above the regional and world averages. Zambia is ranked 23rd among 47 countries in the Sub-Saharan Africa region, and its overall score is below the regional and world averages. ${ }^{2}$ While Zambia is characterized by inefficient legal and regulatory frameworks, weak protection of property rights, and corruption; South Korea fully recognizes property rights and has a well-developed body of laws governing the establishment of commercial enterprises. South Korea today is interested with an ambitious demand-driven economic policy agenda that emphasizes populist spending and "income-led growth" through measures aimed at alleviating debt pressures for households, raising taxes on corporations and the wealthiest, and increasing the minimum wage. In Zambia, there is an abundance of unskilled labor but a shortage of skilled and semiskilled labor. ${ }^{25}$

According to the United Nations Human Development Report, South Korea has become a modern industrial nation and its impressive growth made it a member of OECD 1996. South Korea had miraculously graduated from a developing to a developed nation to the extent that its living standard in 2011 was comparable to that of France. According to its report in 2016, The Human Inequality Coefficient for South Korea is equal to $15.9 \%$. Its progress has been remarkable. ${ }^{3}$ Zambia on the other hand, according to the United Nations Human Development Report economy failed miserable five decades later. The Human Inequality Coefficient for Zambia is equal to $34.7 \%$. It has become a developmental disaster. By the middle of the 1990, the average Zambian citizen could barely afford half the income he did at independence. Kaunda was ousted in disgrace, political unrest was widespread and food riot were wide spread. It equally had to face the AIDS pandemic that was sweeping through

\footnotetext{
1 Michael Shafer, 1990. Sectors, States, and Social Forces: Korea and Zambia Confront Economic Restructuring

${ }^{2}$ The Heritage Foundation | heritage.org/Index

${ }^{3}$ Human Development Report 2016
} 
Africa. In 2011 while Korea was comparing with France, Zambia had one of the worst levels of standard living. With life expectance under 50years, lack of adequate drinking water, mass illiteracy and limited telephone access.

\section{Conclusion: A Proposed Revised Theory of Development}

Development remains a mystery with to precise formula or equation. It should be noted that, there is no precise equation or theory that can specify how a less developed country can move up the development latter. Asian countries like China and our case study South Korea have broken the status quo. From all of the above findings and critical variables, we noticed that two countries, once at the same level of development upon independence, have become two extremes of the continuum. While Korea is seen as a development miracle, Zambia is seen as a development disaster.

There are several proposed theories of economic development like: Mercantilism, Economic nationalism, Post-WWII theories, Linear-stages-of-growth model, Structural-change theory, International dependence theory and Neoclassical theory. After, an insightful look at the critical variables that affected both nations, a revised theory of development is propose below, having to mind that there can be no static formula or equation for development. I propose a development model that includes economic diversification and financial inclusion. A model in which a developing nation does not depend on one major source of revenue for the country but on at least three or more principal sources of nationwide income, so that when one fails like in the case of Copper in Zambia, it can quickly focus on another sector like South Korea who was quick to expand its agricultural, manufacturing and service industry.

Apart from economic diversity, I propose financial inclusion especially in the case of developing countries. Foreign aid should be channeled through the hands of microfinance institutions that are closer to the low income citizens than the governments who embezzle such funds. These microfinance institutions (MFIs) can offer microloans to the common man as capital for investment. Income from this investment goes to repay the loan and even pay taxes to the government. This will massively reduce unemployment and reliance on government, thereby increasing the standard of living, unrest and food riots. Profits from such investments, will lead to expansion and infrastructural development with little effort from the government. Most developed countries are at the agrarian stage of development and subsistence survival (food) is the pressing need of citizens. If these nations can ensure that the common man's belly is filled, it can move to the next level of development. Infrastructural development will be difficult if the citizens can barely feed themselves. Take off in development is very important.

\section{REFRENCES}

Ann Sasa List-Jensen (2008). Economic Development and Authoritarianism - A Case Study on the Korean Developmental State (PDF) (Report). Aalborg University. ISSN 1902-8679. Retrieved 31 July 2012.

Arndt, H. W. (1981). "Economic Development: A Semantic History," Economic Development and Cultural Change, 29(3), p pp. 457-66. Chicago: The Chicago University Press.

Bell, Clive (1987). "Development economics," The New Palgrave: A Dictionary of Economics, v. 1, pp. 818, 825.

BJ Phiri (2010). Civil Control of the Zambian Military since Independence

Ekelund, Robert B., Jr.; Hébert, Robert F. (1997). A History of Economic Theory and Method (4th ed.). Waveland Press [Long Grove, Illinois]. pp. 40-41. ISBN 1-57766-381-0.

Heritage Foundation (2018). Economic Freedom Score in Zambia. Retrieved from https://www.heritage.org/index/country/zambia

Heritage Foundation (2018). Index Economic Freedom Score in South Korea. Retrieved from https://www.heritage.org/index/country/southkorea

Human Development Report (2016). Briefing note for countries on the 2016 Human Development Report on Korea.

James Fry (1980). "The Zambian Economy," in William Tordoff, ed., Administration in Zambia (Madison: University of Wisconsin Press), p. 44

Jeff Friedman (2009). A Crisis of Politics, Not Economics: Complexity, Ignorance, and Policy Failure.

Kisung Park (2008). Military Authoritarian Regimes and Economic Development: The Rok's Economic TakeOff under Park Chung Hee

Kleiner, JüRgen (2001). Korea, A Century of Change. ISBN 978-981-02-4657-0.

Koh, Jae Myong (2018) Green Infrastructure Financing: Institutional Investors, PPPs and Bankable Projects, Palgrave Macmillan, pp.37-39.

$\begin{array}{llllll}\text { Korea's } & \text { economic } & \text { miracle. } & \text { (2017, } & \text { May } & \text { Retrieved }\end{array}$ https://www.washingtontimes.com/news/2017/may/8/south-korea-has-undergone-an-economic-miracle/

Michael Shafer (1990). Sectors, States, and Social Forces: Korea and Zambia Confront Economic Restructuring N Birdsall, F Fukuyama (2011). New Ideas on Development after the Financial Crisis. Baltimore, MD: The 
Johns Hopkins University Press.

R Inglehart, C Welzel (2005). Modernization, Cultural Change, and Democracy: The Human Development Sequence. New York, NY: Cambridge University Press

Ray, Debraj (2008). "development economics". The New Palgrave Dictionary of Economics, 2nd Edition. Abstract.

Seung-Hun Chun (2010). "Strategy for Industrial Development and Growth of Major Industries in Korea" (PDF). Korea Institute for Development Strategy. Archived from the original (PDF) on 11 October 2013. Retrieved 31 July 2012.

South Korea: a model of development? (2011, November 28). Retrieved from https://www.theguardian.com/global-development/poverty-matters/2011/nov/28/south-korea-developmentmodel

South Korea: Finding its place on the world stage. (2010, April). Retrieved from https://www.mckinsey.com/global-themes/asia-pacific/south-korea-finding-its-place-on-the-world-stage

Stuart John (2014). Why Zambia failed. Journal of Institutional Economics. Retrieved from https://www.cambridge.org/core/journals/journal-of-institutional-economics/article/why-zambiafailed/5AD7C4E62B21562E37241093927E4252

Trading Economics (2018). Zambia GDP Annual Growth Rate. Retrieved from https://tradingeconomics.com/zambia/gdp-growth-annual 